\title{
Effect of Alfalfa Silage Storage Structure and Roasting Corn on Production and Ruminal Metabolism of Lactating Dairy Cows ${ }^{1}$
}

\author{
S. J. Krizsan, ${ }^{\star 2}$ G. A. Broderick,† R. E. Muck,† C. Promkot,‡ S. Colombini,§ and Å. T. Randby ${ }^{\star}$ \\ *Department of Animal and Aquacultural Sciences, Norwegian University of Life Sciences, NO-1432 Ås, Norway \\ †Agricultural Research Service, USDA US Dairy Forage Research Center, 1925 Linden Drive West, Madison, WI 53706 \\ ¥Department of Animal Science, Faculty of Agriculture, Khon Kaen University, Khon Kaen 40002, Thailand \\ §Istituto di Zootecnia Generale, Facoltà di Agraria, University of Milano, Italy
}

\begin{abstract}
The objective of this study was to determine if feeding roasted corn would improve production and nutrient utilization when supplemented to lactating cows fed 1 of 3 different alfalfa silages (AS). Forty-two lactating Holstein cows (6 fitted with ruminal cannulas) averaging $77 \mathrm{~d}$ in milk and $43 \mathrm{~kg}$ of milk/d pretrial were assigned to 2 cyclic changeover designs. Treatments were AS ensiled in bag, bunker, or $\mathrm{O}_{2}$-limiting tower silos and supplemented with ground shelled corn (GSC) or roasted GSC (RGSC). Silages were prepared from second-cutting alfalfa, field-wilted an average of $24 \mathrm{~h}$, and ensiled over $2 \mathrm{~d}$. Production and $\mathrm{N}$ utilization were evaluated in 36 cows during four $28-\mathrm{d}$ periods, and ruminal fermentation was evaluated with 6 cows during five 21-d periods. Experimental diets contained $40 \%$ AS, $15 \%$ corn silage, and $35 \%$ of either GSC or RGSC on a dry matter basis. No significant interactions between AS and corn sources were detected for any production trait. Although the chemical composition of the 3 AS was similar, feeding AS from the $\mathrm{O}_{2}$-limited tower silo elicited positive production responses. Yields of $3.5 \%$ fat-corrected milk and fat were increased $1.7 \mathrm{~kg} /$ $\mathrm{d}$ and $150 \mathrm{~g} / \mathrm{d}$, and milk fat content was increased $0.3 \%$ when cows were fed diets based on AS from the $\mathrm{O}_{2^{-}}$ limiting silo compared with the other 2 silages. The responses in milk fat were paralleled by an average increase in acid detergent fiber digestibility of $270 \mathrm{~g} / \mathrm{d}$ for cows fed AS from the $\mathrm{O}_{2}$-limiting tower silo. However, ruminal concentrations of lipogenic volatile fatty acids were unchanged with AS source. Cows fed RGSC consumed $0.6 \mathrm{~kg} / \mathrm{d}$ more dry matter and yielded $30 \mathrm{~g} /$ $\mathrm{d}$ more protein and $50 \mathrm{~g} / \mathrm{d}$ more lactose than cows fed
\end{abstract}

Received December 5, 2006.

Accepted May 27, 2007.

${ }^{1}$ Mention of any trademark or proprietary product in this paper does not constitute a guarantee or warranty of the product by the USDA or the Agricultural Research Service and does not imply its approval to the exclusion of other products that also may be suitable.

${ }^{2}$ Corresponding author: sophie.krizsan@umb.no
GSC diets. There was no evidence of increased total tract digestibility of organic matter or starch, or reduced ruminal $\mathrm{NH}_{3}$ concentration, when feeding RGSC. Free amino acids increased, and isovalerate decreased in rumen fluid from cows fed RGSC diets. However, responses in production with roasted corn were mainly due to increased dry matter intake, which increased the supply of energy and nutrients available for synthesis of milk and milk components.

Key words: alfalfa silage storage structure, dairy cow, milk production, roasted corn

\section{INTRODUCTION}

Ensiling is a common practice on farms, and technologies offer many ways to help ensure consistent preservation. Different options for harvesting and various silo types can affect silage quality (Muck and O'Kiely, 2002). Alfalfa protein can be subject to extensive degradation during ensiling. Alfalfa silage (AS) is high in protein that is rapidly degraded in the rumen. Nonprotein $\mathrm{N}$ in AS may range from 43\% (Nagel and Broderick, 1992) to $87 \%$ (Muck, 1987) of total CP. The NPN in AS is rapidly degraded to ammonia in the rumen and, if not captured as microbial protein, will be absorbed, converted to urea in the liver, and excreted in the urine. Additionally, dietary forage quality may have a more dominant effect on rumen fermentation pattern than source or amount of dietary concentrate (Keady and Mayne, 2001), or supplementation of a glucogenic precursor (Shingfield et al., 2002).

Improvements in milk and protein yield with diets based on AS have been achieved by replacing solventextracted soybean meal with protein sources higher in RUP (Broderick et al., 1990; Faldet and Satter, 1991; Broderick, 1992), and by adding energy to the diets as high moisture corn (HMC; Vagnoni and Broderick, 1997). Moreover, grinding of HMC has increased yield of milk and milk components and reduced ruminal ammonia concentrations (Ekinci and Broderick, 1997). These results indicated that milk production could be 
Table 1. Composition of alfalfa silages stored in 3 types of silos (bag, bunker, and $\mathrm{O}_{2}$-limiting tower silos), corn silage, and ground corn ${ }^{1}$

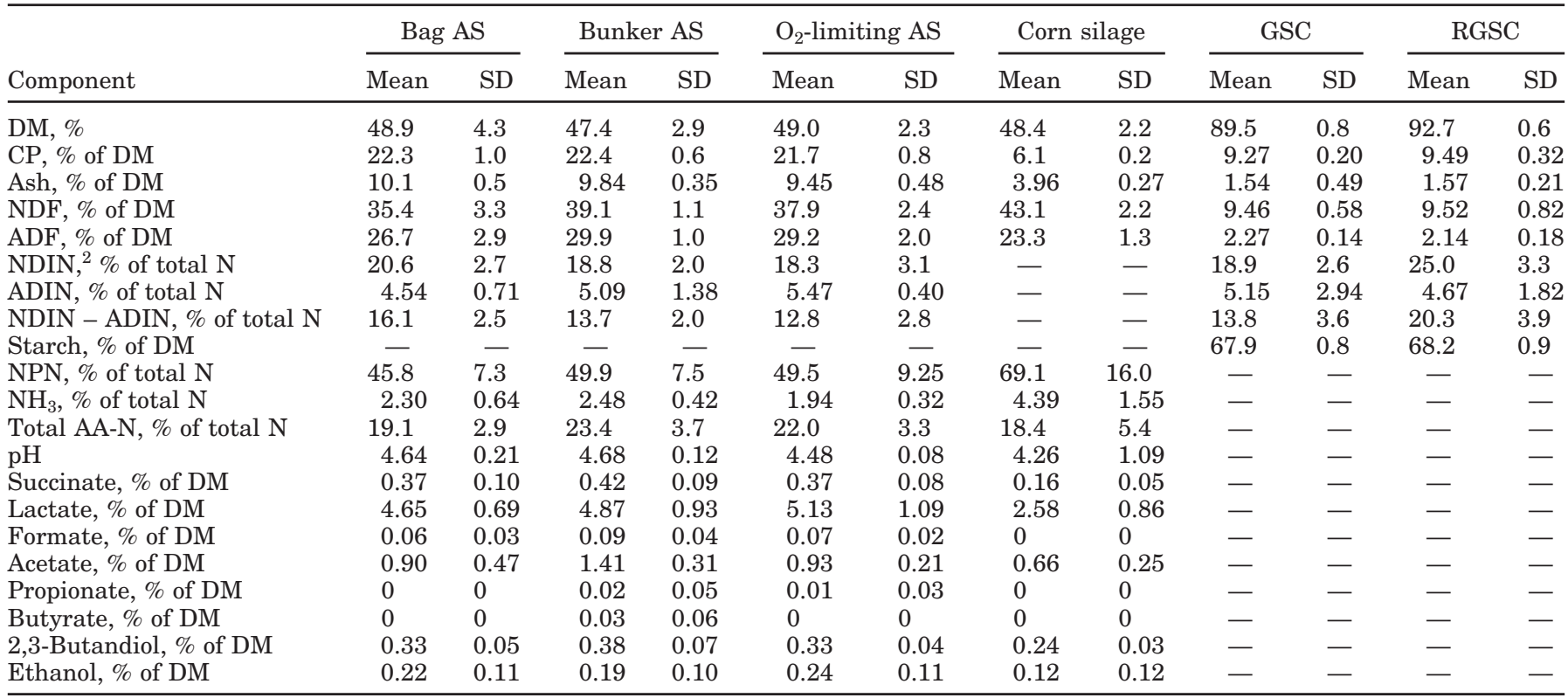

${ }^{1} \mathrm{AS}=$ alfalfa silage, GSC $=$ ground shelled corn, and RGSC $=$ roasted ground shelled corn .

${ }^{2} \mathrm{NDIN}=$ neutral detergent insoluble $\mathrm{N}$.

improved on AS diets by increasing the supply of fermentable energy in the rumen. Roasting dry corn has been proposed as a means of increasing energy availability to the rumen microbes by gelatinizing the starch. Cunningham and Perry (1972) reported more rapid BW gain and improved feed efficiency when growing dairy heifers were fed roasted corn compared with dry corn; however, little research has been performed on feeding of roasted corn to lactating dairy cows.

The objective of this experiment was to determine whether roasting improved utilization of dry shelled corn when fed with alfalfa ensiled in bag, bunker, or $\mathrm{O}_{2}$-limited tower silos, for milk production, $\mathrm{N}$ utilization, and ruminal fermentation in high-yielding dairy cows.

\section{MATERIALS AND METHODS}

\section{Experimental Procedure}

The alfalfa from the same fields was ensiled in 3 different silos: bag (AgBag Systems, Inc., St. Nazianz, WI), bunker, or $\mathrm{O}_{2}$-limited tower silo (Harvestore, Engineered Storage Products Company, DeKalb, IL). Dimensions for bag, bunker, and $\mathrm{O}_{2}$-limited tower silos were $2.4 \mathrm{~m}$ diameter $\times$ approximately $52 \mathrm{~m}$ long, $4.9 \mathrm{~m}$ wide $\times 20.1 \mathrm{~m}$ long $\times 3.5 \mathrm{~m}$ high, and $4.3 \mathrm{~m}$ diameter $\times 15 \mathrm{~m}$ high, respectively. First-cutting alfalfa was harvested over a 2-d period in May 2004, to produce regrowth of similar maturity across all fields. The second- cutting alfalfa was mown June 27-28, 2004, using a New Holland FX 58 forage harvester (CNH Global, New Holland, PA) and field-wilted for an average of $24 \mathrm{~h}$. A portion of each field was allotted to each silo. The alfalfa was ensiled over June 28 to 29, 2004. All forages were chopped to a theoretical length of $2.9 \mathrm{~cm}$ and ensiled after application of a commercial inoculant (H/MF Inoculant, Pharm Tech, Des Moines, IA) to supply $1 \times 10^{5}$ cfu of total lactic acid bacteria/g of wet silage. The bag and bunker silos were filled on both dates, where the $\mathrm{O}_{2}$-limiting silo was filled only on June 29. Drying conditions were good, and no rainfall was recorded during harvest. All AS was weighed and sampled as fed out in 2005 from each silo. Total DM losses in the silos were calculated as gaseous losses plus spoiled silage that was not fed. Gaseous losses were estimated from the ratio of the total amount removed (fed plus spoiled) to total amount filled into each silo. Composition of the 3 sources of AS is in Table 1. Silage densities in bag and bunker silos, calculated from the total amount filled and silo dimensions, were 165 and $296 \mathrm{~kg}$ of $\mathrm{DM} / \mathrm{m}^{3}$, respectively.

The corn grain fed in this trial was either unroasted or roasted using a mobile system consisting of a propane-fired roaster with a throughput rate of $12 \mathrm{t} / \mathrm{h}$ (Roast-A-Matic, Schnupp's Grain Roasting Inc., Lebanon, PA). The corn kernels passed directly through the propane flame (approximate flame temperature of $650^{\circ} \mathrm{C}$ ) and were heated to a temperature of $135^{\circ} \mathrm{C}$ when exiting the roaster. Before the feeding study, a prelimi- 


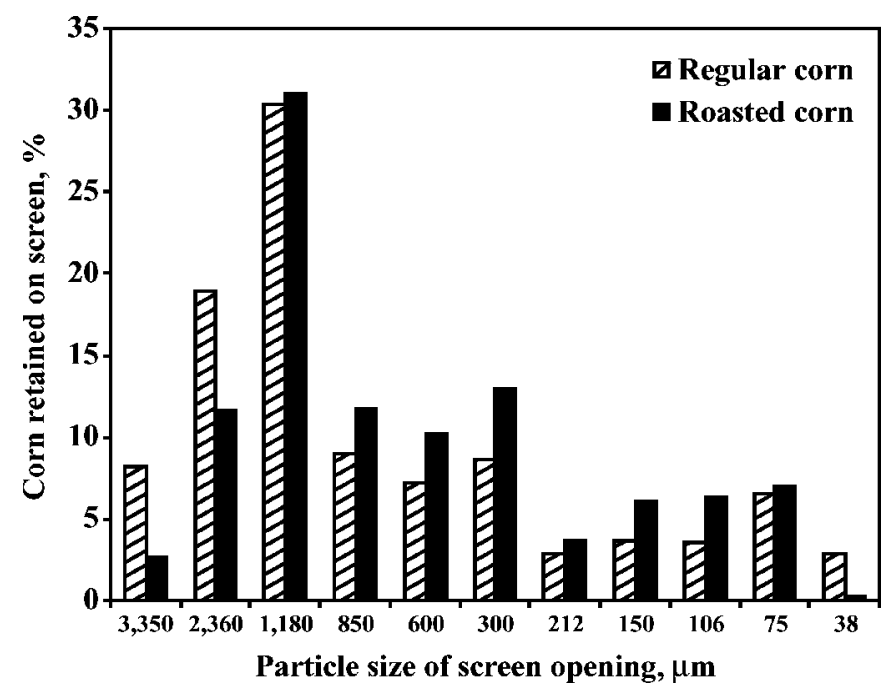

Figure 1. Corn particle size distribution (\% of a 150 -g corn sample) of regular (striped bars) and roasted dry corn (black bars) used in the ruminal metabolism and lactation trial with dairy cows.

nary in vitro incubation was done with dry corn roasted in this manner. Unroasted and roasted corn was ground through 4- and 8-mm screens using a Wiley mill (Arthur H. Thomas, Philadelphia, PA). Duplicate samples of 10 $\mathrm{g}$ of $\mathrm{DM}$ of both grind sizes from control and roasted corn were weighed into 250-mL spinner flasks (Bellco, Vineland, NJ); $100 \mathrm{~mL}$ of McDougall's buffer (McDougall, 1948) was added to each flask. The flasks were held at $39^{\circ} \mathrm{C}$ for $1 \mathrm{~h}$ before adding inoculum. Two blank flasks containing only McDougall's buffer (no corn) were also used. Ruminal contents were collected $2 \mathrm{~h}$ after feeding from 2 cannulated lactating cows consuming $60 \%$ alfalfa silage, $30 \%$ ground corn, and $10 \%$ soybean meal (DM basis). Contents were strained through 4 layers of cheesecloth and equal volumes of the resulting ruminal fluid were blended and brought to $39^{\circ} \mathrm{C}$. Then, $2 \mathrm{~m} M$ cysteine- $\mathrm{HCl}$ and $10 \mathrm{~m} M \mathrm{NH}_{3}$ were added and incubations begun by adding $200 \mathrm{~mL}$ of this inoculum to all flasks. Flasks were incubated at $39^{\circ} \mathrm{C}$ under a $\mathrm{CO}_{2}$ atmosphere with continuous mixing using magnetic stir bars. Duplicate 2-mL aliquots were removed from each flask every hour from time 0 (immediately after inoculating) to $6 \mathrm{~h}$, mixed with $0.5 \mathrm{~mL}$ of $25 \% \mathrm{TCA}$ (wt/vol), and vortexed; samples were held on ice for $30 \mathrm{~min}$ and then centrifuged $\left(10,000 \times g\right.$ for $15 \mathrm{~min}$ at $\left.2^{\circ} \mathrm{C}\right)$. Supernatants were analyzed for $\mathrm{NH}_{3}$ (Broderick et al., 2004) immediately after the incubation. Mean $\mathrm{NH}_{3}$ concentrations from blank vessels and vessels containing corn were plotted as a function of time. The grain to be fed in the lactation trial was augured into trucks directly from the roaster and cooled to ambient temperature on the trucks before being transported and stored in bins until ground. Both unroasted and roasted corn were ground with a hammer mill to produce the control ground shelled corn (GSC) and roasted ground shelled corn (RGSC). A portable, vertically oscillating sieve shaker Ro-Tap RX-29 model (W. S. Tyler Inc., Mentor, $\mathrm{OH})$ was used to determine the particle size distributions of GSC and RGSC by placing approximately 150 $\mathrm{g}$ of sample on the top screen of the stack of sieves and shaking for $20 \mathrm{~min}$. Eleven screens with sieve sizes between 38 and 3,350 $\mu \mathrm{m}$ were used in all determinations. Particle size distribution is shown in Figure 1. The arithmetic mean particle size and percentage of particles recovered on sieves were calculated for each sample as described by Grant et al. (1990). Composition of the 2 corn sources is given in Table 1 .

Forty-two lactating Holstein cows, 30 multiparous (6 fitted with ruminal cannulas) and 12 primiparous, with mean BW of 591 (SD 62) kg, parity 2.3 (SD 1.2), 77 (SD 30) DIM, and producing 43 (SD 6) $\mathrm{kg}$ of milk/d at the start of the trial, were used in 2 separate trials. Production and $\mathrm{N}$ utilization were evaluated using 36 cows in a cyclic changeover design with 3 replications of 2 blocks of 6 cows, in an arrangement with four 28-d periods (Davis and Hall, 1969). Cows were blocked by parity and DIM and, within block, randomly allocated to the sequences of experimental treatments. Cows fitted with ruminal cannulas were used in a separate 1-block cyclic changeover design with five 21-d periods (Davis and Hall, 1969) and randomly assigned to treatment sequence. Dietary treatments were in a $3 \times 2$ factorial arrangement, consisting of the 3 sources of AS and the 2 sources of corn (GSC or RGSC). The experimental diets were fed as TMR and contained (DM basis) $40 \%$ AS, $15 \%$ corn silage, and 35\% of either GSC or RGSC as principal concentrate source (Table 2). The proportions of AS, GSC, and RGSC in the diets as fed were adjusted weekly based on DM determined at $60^{\circ} \mathrm{C}$ for $48 \mathrm{~h}$. Amounts of solvent soybean meal and roasted soybeans were adjusted to provide $17 \% \mathrm{CP}$ across diets. The ratio of corn silage to AS (15:40) was formulated to maintain $28 \% \mathrm{NDF}$ across diets. Cows were housed in tie stalls, had free access to water, and were offered feed once daily at $1200 \mathrm{~h}$; orts were recorded once daily and feeding rate adjusted to yield orts of approximately $10 \%$ of intake. Body weights were measured on 3 consecutive days at the start of the trial and at the end of each period. All cows were injected with bST (500 mg of Posilac; Monsanto, St. Louis, MO) beginning on d 1 of the trial and at 14-d intervals throughout. The Research Animal Resource Center of the University of Wisconsin-Madison approved all procedures involving animal care and experimental procedures.

Weekly composites of corn silage, all $3 \mathrm{AS}$, TMR, and orts were taken from daily samples of about $0.5 \mathrm{~kg}$, and 
Table 2. Composition of experimental diets comprising alfalfa silages (AS) stored in 3 types of silos (bag, bunker, and $\mathrm{O}_{2}$-limiting tower silos) and 2 sources of corn ${ }^{1}$

\begin{tabular}{|c|c|c|c|c|c|c|}
\hline & \multicolumn{2}{|c|}{ Bag AS } & \multicolumn{2}{|c|}{ Bunker AS } & \multicolumn{2}{|c|}{$\mathrm{O}_{2}$-limiting AS } \\
\hline & GSC & RGSC & GSC & RGSC & GSC & RGSC \\
\hline & & & 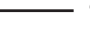 & $\mathrm{DM}$ & & 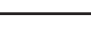 \\
\hline \multicolumn{7}{|l|}{ Ingredient composition } \\
\hline Bag alfalfa silage & 40.0 & 40.1 & - & - & - & - \\
\hline Bunker alfalfa silage & - & - & 41.1 & 41.2 & - & - \\
\hline $\mathrm{O}_{2}$-limiting alfalfa silage & - & - & - & - & 40.5 & 40.6 \\
\hline Corn silage & 14.8 & 14.8 & 14.5 & 14.5 & 14.6 & 14.7 \\
\hline GSC & 35.1 & - & 34.5 & - & 34.8 & - \\
\hline Roasted GSC & - & 34.9 & - & 34.3 & - & 34.6 \\
\hline Solvent soybean meal & 5.11 & 5.12 & 5.02 & 5.03 & 5.07 & 5.08 \\
\hline Roasted soybeans & 4.01 & 4.02 & 3.94 & 3.95 & 3.97 & 3.98 \\
\hline Sodium bicarbonate & 0.50 & 0.50 & 0.49 & 0.49 & 0.50 & 0.50 \\
\hline Salt & 0.20 & 0.20 & 0.20 & 0.20 & 0.20 & 0.20 \\
\hline Dicalcium phosphate & 0.20 & 0.20 & 0.20 & 0.20 & 0.20 & 0.20 \\
\hline Vitamin-mineral mix $^{2}$ & 0.10 & 0.10 & 0.10 & 0.10 & 0.10 & 0.10 \\
\hline \multicolumn{7}{|l|}{ Chemical composition } \\
\hline DM, \% & 66.8 & 67.8 & 66.0 & 66.9 & 66.4 & 67.4 \\
\hline $\mathrm{CP}$ & 17.7 & 17.8 & 17.7 & 17.8 & 17.4 & 17.5 \\
\hline Ash & 6.8 & 6.8 & 6.6 & 6.6 & 6.5 & 6.5 \\
\hline NDF & 25.5 & 25.6 & 26.9 & 27.0 & 26.5 & 26.6 \\
\hline $\mathrm{ADF}$ & 15.4 & 15.4 & 16.7 & 16.7 & 16.5 & 16.5 \\
\hline $\mathrm{Fat}^{3}$ & 3.1 & 3.6 & 3.3 & 3.5 & 3.0 & 3.4 \\
\hline $\operatorname{Starch}^{3}$ & 24.2 & 26.8 & 24.2 & 24.6 & 24.6 & 25.3 \\
\hline $\mathrm{NE}_{\mathrm{Lp}},{ }^{4} \mathrm{Mcal} / \mathrm{kg}$ of $\mathrm{DM}$ & 1.69 & 1.71 & 1.69 & 1.70 & 1.68 & 1.70 \\
\hline
\end{tabular}

${ }^{1} \mathrm{GSC}=$ ground shelled corn, and RGSC $=$ roasted ground shelled corn.

${ }^{2}$ Provided (per kilogram of DM): $56 \mathrm{mg}$ of $\mathrm{Zn}, 46 \mathrm{mg}$ of $\mathrm{Mn}, 22 \mathrm{mg}$ of $\mathrm{Fe}, 12 \mathrm{mg}$ of Cu, $0.9 \mathrm{mg}$ of I, 0.4 $\mathrm{mg}$ of Co, $0.3 \mathrm{mg}$ of Se, 6,440 IU of vitamin A, 2,000 IU of vitamin D, and $16 \mathrm{IU}$ of vitamin E.

${ }^{3}$ Averages content calculated from analyzed TMR samples from each period.

${ }^{4}$ Computed according to NRC (2001) using composition above and tabulated values of lignin to calculate content in diets. The $\mathrm{NE}_{\mathrm{Lp}}$ for each diet was computed from the total digestible nutrient (TDN) value at $1 \times$ maintenance using the relationship between feeding level as multiple of maintenance and the unit decline in diet TDN given by NRC (2001).

stored at $-20^{\circ} \mathrm{C}$. Weekly samples were also taken from solvent soybean meal, roasted soybeans, GSC, and RGSC. The proportion of dietary DM from each ingredient was calculated from the weekly DM determinations of feed samples at $60^{\circ} \mathrm{C}$ for $48 \mathrm{~h}$. After drying, feed ingredients and TMR were ground through a 1-mm screen (Wiley mill; Arthur H. Thomas, Philadelphia, PA). Composites were prepared of the TMR, GSC, and RGSC from the last 2 wk of every period in the production trial. Weekly samples of TMR and feed ingredients were analyzed for total $\mathrm{N}$ using a combustion assay (Leco FP-2000 N analyzer; Leco Instruments, Inc., St. Joseph, MI), and DM content at $105^{\circ} \mathrm{C}$ (AOAC, 1980). These results were used for weekly adjustment of the diet composition. Intake of DM was computed based on the $60^{\circ} \mathrm{C} \mathrm{DM}$ determinations for TMR and orts. Feed ingredients and TMR samples from both experiments were analyzed for $\mathrm{DM}$ at $105^{\circ} \mathrm{C}$, ash content by combustion at $550^{\circ} \mathrm{C}$ for $16 \mathrm{~h}$, total $\mathrm{N}$ by combustion assay, and sequentially for NDF and ADF (Van Soest et al., 1991) using heat-stable $\alpha$-amylase and sodium sulfite (Mertens et al., 2002) in an Ankom Fiber Analyzer (Ankom Technology Corp., Fairport, NY). The N content of
$\mathrm{NDF}$ and ADF residues was determined by the same combustion assay as for total N. Composition of diets was calculated from the chemical composition of the dietary ingredients and proportion of dietary DM from each ingredient. The TMR samples were analyzed for total fat according to AOAC (1997; method 920.39, Dairyland Laboratories, Arcadia, WI) and starch. Samples of GSC and RGSC were also analyzed for starch using a modification of the enzymatic method described by Bach Knudsen (1997). Samples (0.2 g) were weighed into $60-\mathrm{mL}$ tubes with Teflon-lined screw caps. After hydrolysis of the starch to glucose using heat-stable $\alpha$ amylase (1,740 liquefon units added per tube; Spezyme, Genencor Int., Rochester, NY) and amyloglucosidase (100 units added per tube; Megazyme E-AMGDF, Megazyme, Bray, Co. Wicklow, Ireland), the tubes were further incubated at $100^{\circ} \mathrm{C}$ for $30 \mathrm{~min}$. Thereafter, 30 $\mathrm{mL}$ of distilled water was added to each tube and all tubes were mixed by inversion. Total volume of the sample solution was determined as final weight minus initial weight of tube, divided by the density of the sample solution $(0.998 \mathrm{~g} / \mathrm{mL})$. A $2.0-\mathrm{mL}$ aliquot was collected from each tube and centrifuged at $12,000 \times g$ 
for $10 \mathrm{~min}$ to clarify the sample solution. Centrifuged samples were diluted with distilled water to achieve concentrations of glucose that fell within the standard curve range of 0 to $100 \mu \mathrm{g} / \mathrm{mL}$. Samples were analyzed for glucose using a glucose oxidase-peroxidase assay (Karkalas, 1985). Standard cornstarch and blank samples were included in every run. Glucose concentrations were converted to equivalent starch concentrations by multiplying the glucose value by 0.9 .

Extracts from fresh weekly samples of AS were prepared as described by Muck (1987) and $\mathrm{pH}$ was measured. Organic acids (formate, acetate, propionate, butyrate, lactate, and succinate), ethanol, and 2,3-butanediol were analyzed by HPLC using a BioRad Aminex HPX-87H column (BioRad Laboratories, Hercules, CA) at $42^{\circ} \mathrm{C}$ (mobile phase, $0.0075 \mathrm{~N} \mathrm{H}_{2} \mathrm{SO}_{4}$ at $0.6 \mathrm{~mL} / \mathrm{min}$ ) with a refractive index detector (RID-6A, Shimadzu Corp., Kyoto, Japan). A second set of silage extracts were deproteinized and analyzed for NPN according to Muck (1987), and for $\mathrm{NH}_{3}$ and total AA-N by flow injection analysis as described by Broderick et al. (2004). All TMR samples were analyzed for indigestible ADF (IADF; ADF remaining after a 12-d in situ incubations; Huhtanen et al., 1994).

Cows were milked twice daily and yield was recorded at each milking. Milk samples were collected (a.m. and p.m.) on d 19 of each period from all the cows and on d 26 from the 36 cows in the production group. At collection, all milk samples were preserved with 2bromo-2-nitropropane-1,3-diol. Individual a.m. and p.m. milk samples were analyzed for fat, protein, lactose, SNF, and MUN by infrared analysis (Ag-Source, Verona, WI). On d 27 and 28 in each period of the production trial, spot urine and fecal grab samples were collected from all 36 cows $6 \mathrm{~h}$ before and after feeding. Fecal samples were dried in a forced draft oven $\left(60^{\circ} \mathrm{C}\right.$; $72 \mathrm{~h}$ ) and ground through a 1-mm screen (Wiley mill). Equal amounts of DM from each fecal subsample were mixed to obtain one composite sample for each cow in each period. Fecal samples were analyzed for total N, $\mathrm{DM}$, ash, NDF, ADF, starch, and IADF as described earlier. Indigestible $\mathrm{ADF}$ was used as an internal marker to estimate apparent total tract digestibility of nutrients (Cochran et al., 1986). Urine samples (15 mL) were acidified at collection with $60 \mathrm{~mL}$ of $0.072 \mathrm{~N}$ $\mathrm{H}_{2} \mathrm{SO}_{4}$, and stored at $-20^{\circ} \mathrm{C}$. Thawed urine samples were filtered through Whatman no. 1 filter paper. Urine filtrates were analyzed for creatinine (Oser, 1965) and urea (Broderick and Clayton, 1997) by flow injection (Lachat QuikChem 8000, Lachat Instruments, Milwaukee, WI), for total N (VarioMAX, Elementar Americas, Inc., Mt. Laurel, NJ), for allantoin using the method of Vogels and van der Drift (1970) adapted to a 96-well plate reader, and for uric acid using a commercial kit (no. 1830, Thermo, DMA, Waltham, MA). Daily urine volume and excretion of urea $\mathrm{N}$, total $\mathrm{N}$, allantoin, uric acid, and total purine derivatives (allantoin plus uric acid) were estimated using creatinine as a marker assuming an excretion of $29 \mathrm{mg} / \mathrm{kg}$ of BW (Valadares et al., 1999). Blood was collected into heparinized test tubes from the coccygeal artery of each of the 36 cows in the production group on $\mathrm{d} 28$ of each period at $4 \mathrm{~h}$ after feeding. Blood samples were held on ice until stored in the freezer at $-20^{\circ} \mathrm{C}$. Blood was deproteinized by mixing $1.25 \mathrm{~mL}$ of $25 \%$ (wt/vol) TCA with $5 \mathrm{~mL}$ of whole blood, and centrifuged $\left(15,000 \times \mathrm{g}, 4^{\circ} \mathrm{C}, 15 \mathrm{~min}\right)$; supernatants were stored at $-20^{\circ} \mathrm{C}$ until analyzed for urea (Broderick and Clayton, 1997).

Samples of ruminal fluid were collected on d 16 in each of the 5 periods of the ruminal trial from 3 locations in the midventral sac of the rumen of each of the 6 ruminally cannulated cows at 0 (just before feeding), $1,2,4,8,16$, and $24 \mathrm{~h}$ after feeding. Samples were withdrawn using a $60-\mathrm{mL}$ plastic syringe connected to a metal filter probe as described by Olmos Colmenero and Broderick (2006). The $\mathrm{pH}$ of the samples was measured immediately after collection; thereafter, $15 \mathrm{~mL}$ of rumen fluid of each sample was preserved with 0.3 $\mathrm{mL}$ of $50 \%$ ( vol $/ \mathrm{vol}$ ) sulfuric acid, and stored at $-20^{\circ} \mathrm{C}$. Ruminal fluid samples were later thawed and analyzed for VFA (Brotz and Schaefer, 1987), total free AA, and $\mathrm{NH}_{3}$ (Broderick et al., 2004).

\section{Statistical Analyses}

All data were analyzed using the MIXED procedures of SAS (SAS Institute, 1999-2000). Concentrations of $\mathrm{NH}_{3}$ over time in in vitro incubations with roasted and control corn were analyzed according to the model

$$
\begin{gathered}
\mathrm{Y}_{\mathrm{ijkl}}=\mu+\mathrm{R}_{\mathrm{i}}+\mathrm{T}_{\mathrm{j}}+\mathrm{G}_{\mathrm{k}}+\mathrm{H}_{\mathrm{l}}+\mathrm{TG}_{\mathrm{jk}}+\mathrm{TH}_{\mathrm{jl}} \\
+\mathrm{GH}_{\mathrm{kl}}+\mathrm{TGH}_{\mathrm{jkl}}+\mathrm{RTGH}_{\mathrm{ijkl}}+\mathrm{E}_{\mathrm{ijk}},
\end{gathered}
$$

where $Y_{i j k l}=$ dependent variable; $\mu$ = overall mean; $R_{i}=$ effect of replicate $i ; T_{j}=$ effect of roasting treatment $j$; $\mathrm{G}_{\mathrm{k}}=$ effect of grind size $\mathrm{k} ; \mathrm{H}_{\mathrm{l}}=$ effect of incubation hour $\mathrm{l} ; \mathrm{TG}_{\mathrm{jk}}=$ interaction between roasting treatment $\mathrm{j}$ and grind size $\mathrm{k} ; \mathrm{TH}_{\mathrm{jl}}=$ interaction between roasting treatment $\mathrm{j}$ and incubation hour $\mathrm{l} ; \mathrm{GH}_{\mathrm{kl}}=$ interaction between grind size $\mathrm{k}$ and incubation hour $\mathrm{l} ; \mathrm{TGH}_{\mathrm{jkl}}=3$ way interaction between roasting treatment $j$, grind size $\mathrm{k}$, and incubation hour $\mathrm{l} ; \mathrm{RTGH}_{\mathrm{ijkl}}=4$-way interaction between replicate $i$, roasting treatment $j$, grind size $\mathrm{k}$, and incubation hour $\mathrm{l}$; and $\mathrm{E}_{\mathrm{ijkl}}=$ residual error. All terms were considered fixed, except for $\mathrm{R}_{\mathrm{i}}, \mathrm{RTGH}_{\mathrm{ijkl}}$ and $\mathrm{E}_{\mathrm{ijk} k}$, which were considered random.

Average intake and milk production data from each cow over the last $14 \mathrm{~d}$ of each period of the production 
cyclic changeover trial were analyzed according to the model

$$
\begin{gathered}
Y_{\mathrm{ijklm}}=\mu+\mathrm{B}_{\mathrm{i}}+\mathrm{C}_{\mathrm{j}(\mathrm{i})}+\mathrm{P}_{\mathrm{k}}+\mathrm{S}_{\mathrm{l}}+\mathrm{T}_{\mathrm{m}}+\mathrm{ST}_{\mathrm{lm}} \\
+\mathrm{BP}_{\mathrm{ik}}+\mathrm{BST}_{\mathrm{ilm}}+\mathrm{PST}_{\mathrm{klm}}+\mathrm{E}_{\mathrm{ijklm}},
\end{gathered}
$$

where $Y_{\mathrm{ijklm}}=$ the dependent variable in block $\mathrm{i}$ on animal $\mathrm{j}$ in period $\mathrm{k}$ with silage type $\mathrm{l}$ and roasting treatment $\mathrm{m} ; \mu=$ the overall mean; $\mathrm{B}_{\mathrm{i}}=$ effect of block $\mathrm{i}$; $\mathrm{C}_{\mathrm{j}(\mathrm{i})}=$ effect of cow $\mathrm{j}$ within block $\mathrm{i} ; \mathrm{P}_{\mathrm{k}}=$ effect of period $\mathrm{k} ; \mathrm{S}_{\mathrm{l}}=$ effect of silage type $\mathrm{l} ; \mathrm{T}_{\mathrm{m}}=$ effect of roasting treatment $\mathrm{m} ; \mathrm{ST}_{\mathrm{lm}}=$ interaction between silage type 1 and roasting treatment $\mathrm{m} ; \mathrm{BP}_{\mathrm{ik}}=$ interaction between block $\mathrm{i}$ and period $\mathrm{k} ; \mathrm{BST}_{\mathrm{ilm}}=3$-way interaction between block $\mathrm{i}$, silage type 1 , and roasting treatment $\mathrm{m} ; \mathrm{PST}_{\mathrm{klm}}=$ 3 -way interaction between period $\mathrm{k}$, silage type $\mathrm{l}$, and roasting treatment $\mathrm{m}$; and $\mathrm{E}_{\mathrm{ijk} k \mathrm{~m}}=$ random residual. Least squares means are reported and mean separation was done by least significant difference. All terms were considered fixed, except for $\mathrm{C}_{\mathrm{j}(\mathrm{i})}$ and $\mathrm{E}_{\mathrm{ijklm}}$, which were considered random.

A repeated measures model with the $\mathrm{SP}(\mathrm{POW})$ structure of SAS was used to analyze in vivo ruminal $\mathrm{pH}$, concentrations of VFA (acetate, propionate, butyrate, isobutyrate, valerate, and isovalerate), $\mathrm{NH}_{3}$, and total free AA. The model used to analyze main effects was identical to that model presented above except that block was replaced by an effect of hour. Interactions between treatments and hour were considered fixed. Least squares means are reported and mean separation was done by least significant difference.

\section{RESULTS AND DISCUSSION}

\section{Feed Quality and Diet Composition}

The compositions of the AS, corn silage, GSC and RGSC are in Table 1 . There were only small differences in the analyzed composition parameters among the AS. Low contents of $\mathrm{NDF}(<40 \%$ of $\mathrm{DM})$ and $\mathrm{ADF}(<30 \%$ of $\mathrm{DM}$ ), and average $\mathrm{CP}$ content above $22 \%$ of DM indicated that all 3 AS were of high quality. The silages were generally well fermented with comparable $\mathrm{pH}$ and similar levels of fermentation products. However, concentration of $\mathrm{NH}_{3}$ and total AA-N (\% of total N) were highest for the bunker AS and, although the amount was small, butyrate was found only in this silage. Presence of butyrate may have indicated a secondary clostridial fermentation that reduced silage quality (McDonald et al., 1991). In addition, the lactate to acetate ratio was lowest for the bunker AS (3.45), intermediate for the bag AS (5.17), and highest for the AS ensiled in the $\mathrm{O}_{2}$-limited tower silo (5.52), indicating differences in the type of fermentation among the silages. A more heterofermentative lactic acid fermentation will typically be seen in conditions with some oxygen tension (McDonald et al., 1991). The NPN content in all 3 AS was below the average of 54\% from 19 experiments reported by Broderick (1995). Muck (1987) reported that the rate of proteolysis decreased linearly with increases in DM concentrations between 17 and $73 \%$ at ensiling. Likewise, increased silage DM content reduced the rate and extent of fermentation (Muck, 1990). Relatively high and similar DM contents across the 3 AS may explain why larger differences were not observed in NPN content and fermentation characteristics among AS storage structures. Total DM losses, divided between spoiled silage and gaseous losses, were 2.7 and 9.5\% (bag AS), 6.5 and 9.1\% (bunker AS), and 0.1 and $7.0 \%\left(\mathrm{O}_{2}\right.$-limited $\left.\mathrm{AS}\right)$. Observed differences in DM losses among the silos indicated that total losses were greater for bag and bunker silos and lower for the $\mathrm{O}_{2}$-limiting tower silo. Lower concentrations in the DM of $\mathrm{CP}$, ash, and NDF, lower proportion of total $\mathrm{N}$ as $\mathrm{NH}_{3}$, and higher lactate to acetate ratio were all consistent with lower DM losses in the $\mathrm{O}_{2}$-limiting structure.

Roasting increased DM content in the corn fed in the lactation trial by $3 \%$ and increased neutral detergent insoluble N (NDIN) by 6\% (Table 1). Higher NDIN content in RGSC, in addition to slightly lower ADIN, increased the proportion of total $\mathrm{N}$ in NDIN minus ADIN compared with the GSC. This fraction has been characterized as degraded slowly in the rumen, but still digestible and absorbable as AA in the small intestine (Sniffen et al., 1992). Otherwise, there was no indication from chemical composition that roasting altered nutrient content. Mean particle sizes of GSC and RGSC were 567 and $477 \mu \mathrm{m}$, respectively. Particle size distribution of the regular and roasted dry corn is illustrated in Figure 1. The solvent soybean meal and roasted soybeans contained (DM basis, $\pm \mathrm{SD}): 54.6( \pm 0.2)$ and 42.7 $( \pm 4.3) \% \mathrm{CP}$, and $8.1( \pm 2.3)$ and $26.3( \pm 0.5) \% \mathrm{NDF}$, respectively. Ingredient and chemical composition of the 6 diets is in Table 2. Due to variation in ingredient composition, average NDF across diets was $26.4 \%$ rather than $28 \%$, the content for which diets were originally formulated.

\section{Milk Production and Composition}

No significant interactions $(P \geq 0.15)$ between $\mathrm{AS}$ and corn sources were detected for any production trait (Table 3). Yield of 3.5\% FCM and milk fat content and yield were affected $(P<0.01)$, and there was a trend for an effect on feed efficiency $(P=0.10)$, due to source of AS (Table 3). Mean yield of 3.5\% FCM was $1.7 \mathrm{~kg} / \mathrm{d}$ greater $(P<0.01)$ in cows fed AS from the $\mathrm{O}_{2}$-limited silo than AS from the bag and bunker silos. Effect of 
Table 3. Effects of alfalfa silages (AS) stored in 3 types of silos (bag, bunker, and $\mathrm{O}_{2}$-limiting tower silos) and 2 sources of corn ${ }^{1}$ on DMI, BW gain, production efficiency, and milk production and composition

\begin{tabular}{|c|c|c|c|c|c|c|c|c|c|c|}
\hline \multirow[b]{2}{*}{ Item } & \multicolumn{2}{|c|}{ Bag AS } & \multicolumn{2}{|c|}{ Bunker AS } & \multicolumn{2}{|c|}{$\mathrm{O}_{2}$-limiting AS } & \multirow[b]{2}{*}{ SE } & \multicolumn{3}{|c|}{$P>\mathrm{F}^{2}$} \\
\hline & GSC & RGSC & GSC & RGSC & GSC & RGSC & & Corn & Silage & $\mathrm{C} \times \mathrm{S}$ \\
\hline DMI, kg/d & $23.7^{\mathrm{ab}}$ & $24.6^{\mathrm{a}}$ & $24.1^{\mathrm{ab}}$ & $23.9^{\mathrm{ab}}$ & $23.5^{\mathrm{bc}}$ & $24.5^{\mathrm{a}}$ & 0.4 & 0.02 & 0.92 & 0.15 \\
\hline Milk yield, kg/d & 38.5 & 39.9 & 39.4 & 39.2 & 39.3 & 40.1 & 0.8 & 0.09 & 0.60 & 0.34 \\
\hline Milk/DMI & 1.64 & 1.62 & 1.65 & 1.64 & 1.69 & 1.66 & 0.03 & 0.19 & 0.10 & 0.88 \\
\hline $3.5 \% \mathrm{FCM}, \mathrm{kg} / \mathrm{d}$ & $38.0^{\mathrm{c}}$ & $39.9^{\mathrm{abc}}$ & $39.3^{\mathrm{bc}}$ & $39.0^{\mathrm{c}}$ & $41.3^{\mathrm{ab}}$ & $42.2^{\mathrm{a}}$ & 1.02 & 0.18 & $<0.01$ & 0.39 \\
\hline BW gain, $\mathrm{kg} / \mathrm{d}$ & 0.06 & 0.30 & 0.35 & 0.31 & 0.36 & 0.48 & 0.12 & 0.28 & 0.13 & 0.52 \\
\hline \multicolumn{11}{|c|}{ Milk composition and yield } \\
\hline Fat, $\%$ & $3.46^{\mathrm{c}}$ & $3.55^{\mathrm{bc}}$ & $3.49^{\mathrm{c}}$ & $3.44^{\mathrm{c}}$ & $3.79^{\mathrm{a}}$ & $3.76^{\mathrm{ab}}$ & 0.09 & 0.98 & $<0.01$ & 0.66 \\
\hline Fat yield, $\mathrm{kg} / \mathrm{d}$ & $1.31^{\mathrm{c}}$ & $1.40^{\mathrm{bc}}$ & $1.37^{\mathrm{c}}$ & $1.36^{\mathrm{c}}$ & $1.50^{\mathrm{ab}}$ & $1.53^{\mathrm{a}}$ & 0.05 & 0.27 & $<0.01$ & 0.49 \\
\hline Protein, \% & 2.96 & 2.96 & 2.92 & 2.95 & 2.96 & 2.94 & 0.03 & 0.99 & 0.42 & 0.31 \\
\hline Protein yield, kg/d & 1.14 & 1.18 & 1.14 & 1.17 & 1.16 & 1.18 & 0.03 & 0.02 & 0.63 & 0.67 \\
\hline Lactose, \% & 4.83 & 4.84 & 4.84 & 4.84 & 4.84 & 4.83 & 0.03 & 0.92 & 1.00 & 0.69 \\
\hline Lactose yield, $\mathrm{kg} / \mathrm{d}$ & 1.87 & 1.95 & 1.89 & 1.94 & 1.91 & 1.94 & 0.04 & 0.02 & 0.81 & 0.77 \\
\hline $\mathrm{SNF}, \%$ & 8.70 & 8.72 & 8.69 & 8.72 & 8.72 & 8.70 & 0.05 & 0.63 & 0.93 & 0.42 \\
\hline SNF yield, $\mathrm{kg} / \mathrm{d}$ & 3.36 & 3.50 & 3.40 & 3.47 & 3.43 & 3.49 & 0.08 & 0.02 & 0.79 & 0.69 \\
\hline MUN, $\mathrm{mg} / \mathrm{dL}$ & 14.8 & 14.6 & 15.3 & 14.5 & 14.8 & 14.8 & 0.3 & 0.13 & 0.69 & 0.24 \\
\hline
\end{tabular}

${ }^{\mathrm{a}-\mathrm{c}}$ Means within a row with different superscripts $\operatorname{differ}(P<0.05)$.

${ }^{1} \mathrm{GSC}=$ ground shelled corn, and RGSC $=$ roasted ground shelled corn.

${ }^{2}$ Probability of a significant effect of corn type, silage source, and interaction between corn type and silage source $(\mathrm{C} \times \mathrm{S})$.

silage source on milk fat content and yield was similar to that observed for yield of 3.5\% FCM (Table 3). Milk fat content and yield from diets based on AS stored in bag or bunker did not differ $(P>0.67)$. On average, cows fed AS from the bag and bunker silos yielded milk with 0.3 percentage units less milk fat content and secreted $0.15 \mathrm{~kg} / \mathrm{d}$ less milk fat than cows fed AS from the $\mathrm{O}_{2}$-limited silo $(P<0.01)$.

The observed differences in yield of 3.5\% FCM were associated with increases in milk fat content observed on diets containing AS from the $\mathrm{O}_{2}$-limited silo. Huhtanen et al. (2003) analyzed literature relationships among fermentation characteristics in grass silage and milk production parameters and suggested that decreases in milk fat content and yield were associated with increased extent of lactic acid fermentation mediated through both decreased silage DMI and lower proportion of lipogenic VFA produced in the rumen. Diets were fed as TMR, and AS source did not affect total DMI in this study (Table 3). Furthermore, all AS sources had relatively low concentrations of lactic acid (Table 1) and decreases in milk fat in cows fed AS from bag and bunker vs. AS from the $\mathrm{O}_{2}$-limited silo were not likely due to lactic acid. Effects of silage fermentation on milk fat yield were comparable to those on milk fat content (Huhtanen et al., 2003).

Dry matter intake increased by $0.6 \mathrm{~kg} / \mathrm{d}$, and yields of milk protein, lactose, and SNF were increased, respectively, by 30,50 , and $90 \mathrm{~g} / \mathrm{d}$, for cows fed RGSC compared with GSC ( $P=0.02$; Table 3$)$. There was a trend for RGSC to increase milk yield by $0.6 \mathrm{~kg} / \mathrm{d}(P=$ 0.09 ; Table 3). The dry-heat processing of roasting has been reported to gelatinize cornstarch (Reeve and Walker, 1969). Felsman et al. (1972) reported increased in vitro glucose release within a 5 -h period and increased DM digestibility by beef cattle as the roasting temperature of the corn was increased from 116 to $137^{\circ} \mathrm{C}$. A more rapid decline in $\mathrm{NH}_{3}$ in ruminal in vitro incubations containing roasted corn suggested increased microbial growth (Figure 2); mean $\mathrm{NH}_{3}$ concentration over all times for both grind sizes was $2.5 \mathrm{mM}$ lower $(P<0.01)$ for roasted corn. This suggested that

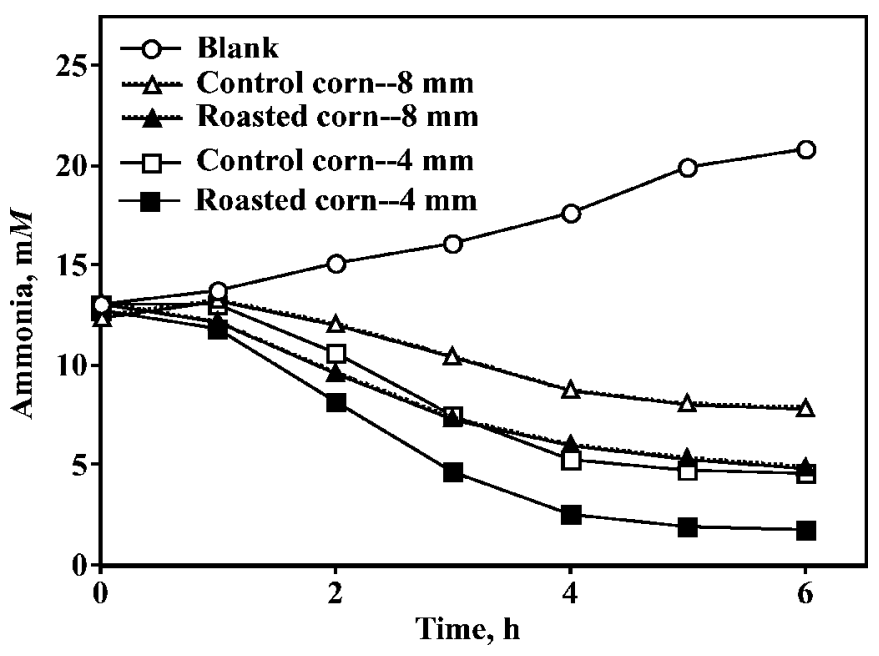

Figure 2. Concentrations of $\mathrm{NH}_{3}$ in ruminal in vitro blank incubations (no added carbohydrate) and in vitro incubations with control or roasted dry shelled corn that had been ground through 4-mm or 8-mm screens. Mean $\mathrm{NH}_{3}$ concentration was reduced $(P<0.01)$ by $2.50 \mathrm{~m} M$ at both grind sizes in incubations containing roasted corn. 
Table 4. Effects of alfalfa silages (AS) stored in 3 types of silos (bag, bunker, and $\mathrm{O}_{2}$-limiting tower silos) and 2 sources of $\operatorname{corn}^{1}$ on intake and estimated apparent total tract digestibility

\begin{tabular}{|c|c|c|c|c|c|c|c|c|c|c|}
\hline \multirow[b]{2}{*}{ Item } & \multicolumn{2}{|c|}{ Bag AS } & \multicolumn{2}{|c|}{ Bunker AS } & \multicolumn{2}{|c|}{$\underline{\mathrm{O}_{2} \text {-limiting AS }}$} & \multirow[b]{2}{*}{$\mathrm{SE}$} & \multicolumn{3}{|c|}{$P>\mathrm{F}^{2}$} \\
\hline & GSC & RGSC & GSC & RGSC & GSC & RGSC & & Corn & Silage & $\mathrm{C} \times \mathrm{S}$ \\
\hline \multicolumn{11}{|c|}{ Intake, $\mathrm{kg} / \mathrm{d}$} \\
\hline DM & $23.7^{\mathrm{ab}}$ & $24.6^{\mathrm{a}}$ & $24.1^{\mathrm{ab}}$ & $23.9^{\mathrm{ab}}$ & $23.5^{\mathrm{bc}}$ & $24.5^{\mathrm{a}}$ & 0.4 & 0.02 & 0.92 & 0.15 \\
\hline $\mathrm{OM}$ & $22.0^{\mathrm{b}}$ & $22.9^{\mathrm{a}}$ & $22.4^{\mathrm{ab}}$ & $22.3^{\mathrm{ab}}$ & $21.8^{\mathrm{b}}$ & $22.9^{\mathrm{a}}$ & 0.4 & 0.01 & 0.96 & 0.12 \\
\hline $\mathrm{CP}$ & $4.22^{\mathrm{bc}}$ & $4.40^{\mathrm{a}}$ & $4.35^{\mathrm{ab}}$ & $4.32^{\mathrm{ab}}$ & $4.08^{\mathrm{c}}$ & $4.23^{\mathrm{bc}}$ & 0.08 & 0.03 & $<0.01$ & 0.15 \\
\hline NDF & $7.00^{\mathrm{bc}}$ & $6.82^{\mathrm{c}}$ & $7.45^{\mathrm{a}}$ & $7.04^{\mathrm{bc}}$ & $7.19^{\mathrm{ab}}$ & $7.43^{\mathrm{a}}$ & 0.13 & 0.12 & $<0.01$ & $<0.01$ \\
\hline $\mathrm{ADF}$ & $4.50^{\mathrm{bc}}$ & $4.34^{\text {bd }}$ & $4.30^{\mathrm{d}}$ & $4.48^{\mathrm{b}}$ & $4.68^{\mathrm{a}}$ & $4.77^{\mathrm{a}}$ & 0.08 & 0.42 & $<0.01$ & 0.03 \\
\hline Starch & $5.73^{\mathrm{c}}$ & $6.57^{\mathrm{a}}$ & $5.83^{\mathrm{c}}$ & $5.87^{\mathrm{c}}$ & $5.78^{\mathrm{c}}$ & $6.21^{\mathrm{b}}$ & 0.11 & $<0.01$ & $<0.01$ & $<0.01$ \\
\hline \multicolumn{11}{|c|}{ Apparent digestibility, ${ }^{3} \%$} \\
\hline DM & 60.5 & 61.4 & 59.4 & 59.4 & 60.2 & 60.3 & 0.9 & 0.67 & 0.18 & 0.84 \\
\hline $\mathrm{OM}$ & 61.5 & 62.6 & 60.6 & 60.5 & 61.1 & 61.3 & 0.9 & 0.57 & 0.20 & 0.77 \\
\hline $\mathrm{CP}$ & 53.5 & 53.6 & 50.2 & 50.6 & 52.9 & 51.4 & 1.4 & 0.74 & 0.06 & 0.74 \\
\hline NDF & $42.7^{\mathrm{c}}$ & $41.9^{\mathrm{c}}$ & $45.7^{\mathrm{ab}}$ & $42.5^{\mathrm{c}}$ & $45.8^{\mathrm{ab}}$ & $44.1^{\mathrm{bc}}$ & 0.8 & 0.01 & 0.01 & 0.34 \\
\hline $\mathrm{ADF}$ & $42.7^{\mathrm{bc}}$ & $41.6^{\mathrm{cd}}$ & $39.3^{\mathrm{d}}$ & $42.0^{\mathrm{bc}}$ & $46.4^{\mathrm{a}}$ & $44.0^{\mathrm{b}}$ & 0.8 & 0.64 & $<0.01$ & 0.01 \\
\hline Starch & 84.1 & 83.8 & 85.4 & 84.9 & 83.8 & 84.3 & 2.0 & 0.94 & 0.59 & 0.94 \\
\hline
\end{tabular}

${ }^{\mathrm{a}-\mathrm{d}}$ Means within a row with different superscripts differ $(P<0.05)$.

${ }^{1} \mathrm{GSC}=$ ground shelled corn, and RGSC $=$ roasted ground shelled corn.

${ }^{2}$ Probability of a significant effect of corn type, silage source, and interaction between corn type and silage source $(\mathrm{C} \times \mathrm{S})$.

${ }^{3}$ Estimated using the indigestible $\mathrm{ADF}$ content in TMR and feces as internal marker.

RGSC would provide greater ruminal fermentable energy than GSC when fed in the lactation trial. Diets based on AS with high levels of NPN have shown increased yield of milk and protein by increasing ruminal carbohydrate fermentation (Ekinci and Broderick, 1997) or by adjusting the ratio of fermentable energy to RDP (Vagnoni and Broderick, 1997; Broderick, 2003). The differences between GSC and RGSC diets in DMI and protein yield were relatively small in this study, and there was only a tendency for increased milk yield with roasted corn. Finely ground corn has more extensive ruminal digestion of starch compared with medium- or coarse-rolled corn (Rémond et al., 2004). It is likely that higher level of NPN in the AS or coarser processing of the corn may have increased the production response to roasting in the present study.

\section{Intake and Apparent Digestibility}

Intakes of DM, OM, CP, and starch were altered by corn source $(P \leq 0.03)$. Intake of $\mathrm{CP}$ and starch was also influenced by AS source $(P<0.01)$, and there was an interaction between corn and AS source for starch intake $(P<0.01$; Table 4$)$. In addition, effect of AS source and the interaction term were both significant for NDF and ADF intake $(P \leq 0.03$; Table 4$)$. Higher DM content in experimental diets containing RGSC (Table 2) may explain the observed $0.6 \mathrm{~kg} / \mathrm{d}$ greater DMI. Differences in intake of OM, CP, and starch due to corn type paralleled the changes in DMI, but greater starch intake could have resulted partly from the higher concentrations of starch observed in the RGSC diets (Table 2).
In addition, diets with $\mathrm{AS}$ from the $\mathrm{O}_{2}$-limiting silo contained 0.3 percentage units less $\mathrm{CP}$, which was consistent with higher $\mathrm{CP}$ intake on diets from the bag and bunker silos. Moreover, differences in NDF content between AS sources (Table 1) and diets (Table 2) probably explained observed differences in NDF intake. Additionally, the proportion of dietary DM from AS was slightly higher for the diets made using AS from bunker and $\mathrm{O}_{2}$-limiting silos. Average dietary starch content across AS source and proportion of dietary DM from corn silage and dry corn paralleled the differences in intake of starch due to AS source. The effect of AS source on $\mathrm{ADF}$ intake was not compatible with differences in $\operatorname{diet} \mathrm{ADF}$ content. Likewise, the significant changes in intake due to an interaction between corn type and AS source on $\mathrm{NDF}, \mathrm{ADF}$, and starch are difficult to explain.

Apparent total tract digestibility of NDF and ADF were affected by AS source $(\mathrm{P} \leq 0.01)$, apparent digestibility of NDF was affected by corn type $(P=0.01)$, and there was an interaction between corn and AS source for apparent digestibility of $\mathrm{ADF}(P=0.01$; Table 4$)$. In addition, apparent total tract digestibility of $\mathrm{CP}$ tended to be affected by AS source $(P=0.06$; Table 4$)$. It was surprising that the different AS sources in this study induced changes in $\mathrm{CP}, \mathrm{NDF}$, and ADF digestibility, because all fields were second-cutting regrowth of equal maturity when ensiled. Higher NDF concentration in the bunker AS (Table 1) was in accordance with the observed higher DM losses in that silo, and a lower fiber digestibility could be expected despite the fact that $\mathrm{NDF}$ intake on bunker AS diets was equal to that on diets containing AS from the $\mathrm{O}_{2}$-limiting silo. However, 
digestibility of NDF for these diets could not be separated $(P=0.33)$. Means of ADF digestibility for cows fed AS diets from bag, bunker, and the $\mathrm{O}_{2}$-limiting tower silo were $42.2,40.7$, and $45.2 \%$, respectively, and ADF digestibility from both bag and bunker silos was lower $(P<0.01)$ than for cows fed AS from the $\mathrm{O}_{2^{-}}$ limiting tower silo. Increased apparent digestibility of $\mathrm{ADF}$ for cows fed $\mathrm{AS}$ from the $\mathrm{O}_{2}$-limiting tower silo coincided with the observed increase in milk fat content and yield of milk fat and 3.5\% FCM. Most major species of ruminal bacteria that digest structural carbohydrate ferment cellulose mainly to lipogenic VFA (Van Soest, 1994). The finding of higher ADF digestibility for cows fed AS from the $\mathrm{O}_{2}$-limiting silo, combined with the greater ADF intake on these diets, resulted in $270 \mathrm{~g} / \mathrm{d}$ greater total tract digestion compared with the diets from the 2 other AS sources. Intake of CP on AS diets from the bag and bunker were comparable in magnitude ( 4.31 and $4.34 \mathrm{~kg} / \mathrm{d}$, respectively) and higher $(P \leq 0.01)$ than intake of $\mathrm{CP}$ on AS diets from the $\mathrm{O}_{2}$-limited silo $(4.16 \mathrm{~kg} / \mathrm{d})$. Increased apparent digestibility of CP is usually observed when there is increased intake of dietary CP due to dilution of metabolic fecal N, and true digestibility of protein may not necessarily be increased. The fact that apparent CP digestibility on bunker AS diets was lower than on bag AS diets $(P=0.02)$ in this study (53.5 vs. $50.4 \%$ ) could indicate a reduction in true CP digestibility of that diet.

The observed decrease in apparent total tract digestibility of NDF with RGSC diets was in accordance with other findings of reduced fiber digestibility when increasing ruminal fermentation of starch (Overton et al., 1995; Broderick 2003). Roasting did not alter the apparent total tract digestibility of starch $(P=0.94$; Table 4). This is not in agreement with our preliminary observation of increased ruminal $\mathrm{NH}_{3}$ uptake (Figure 2) and other results showing increased starch digestibility with enhanced processing of corn or increased intake of fermentable carbohydrates (Ekinci and Broderick, 1997; Lykos et al., 1997; Krause et al., 2003). Rémond et al. (2004) observed decreased total tract digestibility of starch with increases in mean particle size from 0.6 to $3.7 \mathrm{~mm}$. The effect of roasting on total tract digestibility of starch in this study probably did not result because of the small difference in particle size of the corn. The interaction between corn and AS source for apparent ADF digestibility differentiated between bunker and tower AS sources (Table 4). This can be explained, in part, by the difference in ADF intakes (Table 4). Moreover, the apparent total tract digestibility of DM, $\mathrm{OM}, \mathrm{CP}$, and starch in this study was lower than expected. Levels of apparent total tract digestibility of $\mathrm{OM}, \mathrm{CP}$, and starch above 70,65 , and $90 \%$ have been reported for diets with ground corn as the principal concentrate source (Rémond et al., 2004). These results suggested that IADF concentrations might have been underestimated in the feces or overestimated in the feed, resulting in underestimation of digestibility.

In the study of Lykos et al. (1997), no effect of diet on DMI was observed, but increased ruminal degradation rates of starch elicited a positive response in milk production. Additionally, smaller particle sizes and higher passage rates with the diet highest in ground HMC increased starch digestibility in the small intestine, total tract digestibility of starch, and total tract digestibility of OM (Lykos et al., 1997). Treatment effects on production were related to increased nutrient and energy availability. There was no association between the effects of RGSC on production parameters and the digestibility data of this study. The tendency for increased milk yield and the response in yield of nonfat components with RGSC diets were probably related to increased DMI.

\section{Ruminal Metabolism and Nitrogen Utilization and Excretion}

Generally, there were few effects of diet on ruminal metabolites in this study (Table 5). There were no changes due to diet in total or individual VFA concentrations $(P \geq 0.32)$ over the 24 -h sampling period. An increase in total VFA with RGSC diets could be expected because roasting was expected to increase ruminal fermentability of the dietary starch (Figure 1). Ekinci and Broderick (1997), Vagnoni and Broderick (1997), and Krause et al. (2003) did not detect any changes in total ruminal VFA concentrations, but percentage of acetate was lower and percentage of propionate higher when more rapidly available starch sources were fed. A shift in ruminal fermentation pattern with decreased acetate to propionate ratio is consistent with what would be expected from increased carbohydrate fermentation. On the other hand, no effect of AS source on ruminal production of lipogenic VFA was observed, consistent with the observed increases in milk fat yield and content with AS diets from the $\mathrm{O}_{2}$-limiting silo. Concentrations of VFA in the rumen are a balance between production and disappearance or interconversion, and important differences in production rates may not be apparent from concentrations or molar proportions (Firkins et al., 2006). Ruminal pH tended to be depressed $(P=0.07)$ for cows fed GSC compared with RGSC (Table 5). This was unexpected and in contrast with the results of Overton et al. (1995), Lykos et al. (1997), and Vagnoni and Broderick (1997), which showed a mean reduction in $\mathrm{pH}$ with an increased amount of more rapidly fermentable carbohydrates. Ruminal $\mathrm{pH}$ was affected by hour of sampling $(P<0.01)$ 
Table 5. Effects of alfalfa silages (AS) stored in 3 types of silos (bag, bunker, and $\mathrm{O}_{2}$-limiting tower silos) and 2 sources of corn ${ }^{1}$ on ruminal metabolites

\begin{tabular}{|c|c|c|c|c|c|c|c|c|c|c|}
\hline \multirow[b]{2}{*}{ Metabolites } & \multicolumn{2}{|c|}{ Bag AS } & \multicolumn{2}{|c|}{ Bunker AS } & \multicolumn{2}{|c|}{$\mathrm{O}_{2}$-limiting AS } & \multirow[b]{2}{*}{$\mathrm{SE}$} & \multicolumn{3}{|c|}{$P>\mathrm{F}^{2}$} \\
\hline & GSC & RGSC & GSC & RGSC & GSC & RGSC & & Corn & Silage & $\mathrm{C} \times \mathrm{S}$ \\
\hline $\mathrm{pH}$ & 6.35 & 6.46 & 6.38 & 6.41 & 6.37 & 6.46 & 0.07 & 0.07 & 0.94 & 0.43 \\
\hline Free AA, $\mathrm{m} M$ & $2.56^{\mathrm{c}}$ & $4.81^{\mathrm{a}}$ & $2.09^{\mathrm{b}}$ & $4.70^{\mathrm{ab}}$ & $2.96^{\mathrm{c}}$ & $3.30^{\mathrm{bc}}$ & 0.54 & $<0.01$ & 0.58 & 0.07 \\
\hline Total VFA, mM & 100 & 104 & 102 & 98.1 & 110 & 99.7 & 5.2 & 0.33 & 0.50 & 0.22 \\
\hline Acetate (A), $\mathrm{m} M$ & 62.8 & 65.7 & 63.8 & 62.9 & 69.5 & 63.3 & 3.0 & 0.48 & 0.43 & 0.11 \\
\hline Propionate $(\mathrm{P}), \mathrm{m} M$ & 21.2 & 21.8 & 22.1 & 20.0 & 22.6 & 20.7 & 1.6 & 0.31 & 0.91 & 0.68 \\
\hline Isobutyrate, $\mathrm{m} M$ & 1.08 & 1.05 & 1.03 & 1.03 & 1.09 & 1.02 & 0.05 & 0.17 & 0.39 & 0.20 \\
\hline Valerate, $\mathrm{m} M$ & 1.71 & 1.68 & 1.69 & 1.64 & 1.81 & 1.69 & 0.12 & 0.46 & 0.71 & 0.77 \\
\hline Isovalerate, $\mathrm{m} M$ & $1.68^{\mathrm{ab}}$ & $1.48^{\mathrm{c}}$ & $1.55^{\mathrm{abc}}$ & $1.56^{\mathrm{abc}}$ & $1.69^{\mathrm{a}}$ & $1.54^{\mathrm{bc}}$ & 0.09 & $<0.01$ & 0.57 & 0.03 \\
\hline Branched-chain VFA, $\mathrm{m} M$ & $2.75^{\mathrm{ab}}$ & $2.53^{\mathrm{c}}$ & $2.58^{\mathrm{abc}}$ & $2.59^{\mathrm{abc}}$ & $2.78^{\mathrm{a}}$ & $2.56^{\mathrm{bc}}$ & 0.13 & 0.02 & 0.53 & 0.06 \\
\hline
\end{tabular}

${ }^{\mathrm{a}-\mathrm{c}}$ Means within a row with different superscripts differ $(P<0.05)$.

${ }^{1} \mathrm{GSC}=$ ground shelled corn, and RGSC $=$ roasted ground shelled corn.

${ }^{2}$ Probability of a significant effect of corn type, silage source, and interaction between corn type and silage source $(\mathrm{C} \times \mathrm{S})$.

in this study. There was an immediate decline in $\mathrm{pH}$ for all diets after feeding, reaching a minimum value at $8 \mathrm{~h}$ (for cows fed bunker AS diets and tower AS plus RGSC) or $12 \mathrm{~h}$ (with bag AS diets and tower AS plus GSC). The minimum $\mathrm{pH}$ values (ranging from 5.90 to 6.12 ) at 8 and $12 \mathrm{~h}$ across diets were not significantly different $(P \geq 0.47)$. A subsequent increase following minimum $\mathrm{pH}$ was observed for all diets. It is likely that the ruminal degradability of cornstarch was high irrespective of roasting in this study, and the small difference in mean $\mathrm{pH}$ of 6.36 and 6.44 for cows fed GSC and RGSC diets, respectively, was of minor importance. Fineness of the grind could also explain why ruminal total and individual VFA concentrations were not affected by corn type in this study. The concentrations of isovalerate and total branched-chain VFA (BCVFA) in ruminal fluid were lower $(P \leq 0.02)$ for cows fed RGSC than for cows fed GSC (Table 5). The interaction term for corn and AS source was also significant $(P=0.03)$ for ruminal isovalerate concentration, indicating that the effect of corn was not observed in bunker AS diets (Table 5). Lykos et al. (1997) also observed decreased concentration of BCVFA with increased rate of ruminal degradation of cornstarch. The BCVFA are end products of protein degradation (Andries et al., 1987), and a decrease in concentration could indicate reduced protein breakdown in the rumen. The decrease in BCVFA, if accompanied by a decrease in ruminal $\mathrm{NH}_{3}$ concentration, could indicate greater microbial protein synthesis (Firkins et al., 2006). Lykos et al. (1997) observed decreases in ruminal $\mathrm{NH}_{3}$ concentration with increases in the level of ruminal available carbohydrates in the diets. There was no indication of improved in vivo utilization of $\mathrm{NH}_{3}$ by ruminal microbes due to corn or AS source $(P \geq 0.18)$ in this study (Table 5$)$. However, total free AA concentration increased in rumen fluid from cows fed RGSC diets compared with cows fed GSC diets $(P<0.01$; Table 5). The concentration of total free AA in rumen fluid was relatively high and reflected the extensive ruminal degradation of $\mathrm{CP}$ in the diets fed in this experiment as well as the large amount of $\mathrm{N}$ present as peptides and free AA in AS.

Dietary effects on variables related to $\mathrm{N}$ utilization and excretion are in Table 6. In contrast to other reports showing decreased milk or blood urea with dietary increased ruminal degradability of carbohydrates (Ekinci and Broderick, 1997; Lykos et al., 1997; Broderick, 2003), there was no indication of more efficient use of $\mathrm{N}$ by cows fed RGSC vs. GSC ( $P \geq 0.13$; Table 6$)$. Urinary excretion of allantoin and uric acid was also not affected by corn source $(P \geq 0.83)$, suggesting that microbial protein synthesis was not altered (Table 6 ). In the study of Olmos Colmenero and Broderick (2006), increased urine volume was associated with increased urinary $\mathrm{N}$ excretion and a higher proportion of urinary $\mathrm{N}$ as urea. Although urine volume was affected by AS source $(P=$ 0.05 ; Table 6), mean volumes for bag, bunker, and $\mathrm{O}_{2}$ limiting tower AS diets were $20.5,21.7$, and $21.1 \mathrm{~L} / \mathrm{d}$, respectively, and means could not be separated $(P \geq$ $0.12)$. Neither was there evidence for altered urinary excretion of $\mathrm{N}$ due to AS source $(P \geq 0.67)$. However, there were trends $(P=0.06)$ for increased fecal N excretion in amount and as proportion of $\mathrm{N}$ intake with bunker AS diets (Table 6). These trends were consistent with the observation of lower apparent digestibility of $\mathrm{CP}$ in the bunker AS vs. bag AS (Table 4). The tendencies for increased urinary $\mathrm{N}(P=0.07)$ and urea excretion $(P=0.09)$ with RGSC diets paralleled the increased intake of CP due to corn type (Table 4). Furthermore, there were no changes in $\mathrm{N}$ utilization (Table 5) or $\mathrm{N}$ 
Table 6. Effects of alfalfa silages (AS) stored in 3 types of silos (bag, bunker, and $\mathrm{O}_{2}$-limiting tower silos) and 2 sources of corn ${ }^{1}$ on $\mathrm{N}$ metabolism

\begin{tabular}{|c|c|c|c|c|c|c|c|c|c|c|}
\hline \multirow[b]{2}{*}{ Item } & \multicolumn{2}{|c|}{ Bag AS } & \multicolumn{2}{|c|}{ Bunker AS } & \multicolumn{2}{|c|}{$\mathrm{O}_{2}$-limiting AS } & \multirow[b]{2}{*}{ SE } & \multicolumn{3}{|c|}{$P>\mathrm{F}^{2}$} \\
\hline & GSC & RGSC & GSC & RGSC & GSC & RGSC & & Corn & Silage & $\mathrm{C} \times \mathrm{S}$ \\
\hline $\mathrm{BUN}, \mathrm{mg} / \mathrm{dL}$ & 14.1 & 14.0 & 15.2 & 14.6 & 14.0 & 15.0 & 0.5 & 0.78 & 0.14 & 0.14 \\
\hline \multicolumn{11}{|l|}{ Urinary excretion } \\
\hline Urine volume, $\mathrm{L} / \mathrm{d}$ & 20.1 & 20.8 & 21.2 & 22.2 & 20.1 & 22.1 & 0.9 & 0.30 & 0.05 & 0.68 \\
\hline Total N, g/d & 166 & 164 & 162 & 169 & 162 & 170 & 4 & 0.07 & 0.96 & 0.28 \\
\hline Total $\mathrm{N}, \%$ of $\mathrm{N}$ intake & 24.7 & 23.4 & 23.5 & 24.5 & 24.8 & 25.0 & 0.6 & 0.94 & 0.12 & 0.07 \\
\hline Allantoin, $\mathrm{mmol} / \mathrm{d}$ & 338 & 356 & 345 & 345 & 351 & 329 & 12 & 0.84 & 0.74 & 0.16 \\
\hline Uric acid, $\mathrm{mmol} / \mathrm{d}$ & 50.0 & 53.2 & 54.0 & 49.1 & 50.5 & 52.0 & 2.2 & 0.83 & 0.97 & 0.12 \\
\hline Purine derivatives, $\mathrm{mmol} / \mathrm{d}$ & 388 & 409 & 399 & 394 & 401 & 381 & 12 & 0.87 & 0.77 & 0.15 \\
\hline \multicolumn{11}{|l|}{ Fecal excretion } \\
\hline $\mathrm{DM}, \mathrm{kg} / \mathrm{d}$ & 9.34 & 9.54 & 9.73 & 9.78 & 9.40 & 9.72 & 0.32 & 0.39 & 0.54 & 0.89 \\
\hline $\mathrm{N}, \mathrm{g} / \mathrm{d}$ & $314^{\mathrm{b}}$ & $329^{\mathrm{ab}}$ & $346^{\mathrm{a}}$ & $342^{\mathrm{a}}$ & $308^{\mathrm{b}}$ & $329^{\mathrm{ab}}$ & 13 & 0.24 & 0.06 & 0.53 \\
\hline $\mathrm{N}, \%$ of $\mathrm{N}$ intake & 46.1 & 46.5 & 49.8 & 49.4 & 47.2 & 48.6 & 1.4 & 0.75 & 0.06 & 0.73 \\
\hline
\end{tabular}

${ }^{\mathrm{a}, \mathrm{b}}$ Means within a row with different superscripts differ $(P<0.05)$.

${ }^{1} \mathrm{GSC}=$ ground shelled corn, and RGSC $=$ roasted ground shelled corn.

${ }^{2}$ Probability of a significant effect of corn type, silage source, and interaction between corn type and silage source $(\mathrm{C} \times \mathrm{S})$.

efficiency with corn type (Table 6). Overall, differences in $\mathrm{N}$ utilization were most likely not detected due to the small differences in chemical composition among the $3 \mathrm{AS}$ sources and the similar digestibility of starch on the 2 corn sources.

\section{CONCLUSIONS}

The relatively small differences in chemical composition in AS from the different silo structures may have been due to effects of DM content at ensiling. However, DM losses and lactate to acetate ratio were lower in the $\mathrm{O}_{2}$-limited silo. Despite no observed influence on rumen fermentation pattern, AS from the $\mathrm{O}_{2}$-limiting tower silo elicited positive responses in yield of 3.5\% FCM, which derived from increased milk fat content and yield. The production responses due to AS source corresponded with an observed increase in fiber digestibility for cows fed AS from the $\mathrm{O}_{2}$-limiting tower silo. Dry matter intake increased, as did yields of milk protein, lactose, and SNF, for cows fed RGSC compared with GSC. There was also a trend for RGSC diets to increase milk yield. The responses in production with roasted corn were mainly due to increased DMI, which increased the supply of energy and nutrients available for synthesis of milk and milk components. Although roasting increased $\mathrm{NH}_{3}$ uptake in vitro, there was no indication of improved in vivo utilization of $\mathrm{NH}_{3}$ by ruminal microbes, or increased carbohydrate fermentation or digestibility, with different corn sources.

\section{ACKNOWLEDGMENTS}

The authors thank Jill Davidson and the barn crew for feeding and animal care at the US Dairy Forage
Research Center Farm (Prairie du Sac, WI); Mary Beth Hall for the starch analysis assay; Santiago Reynal, Wendy Radloff, and Mary Becker for laboratory analyses; Francisco Contreras for HPLC analysis; José Lebovich, Steve Diederich, and Tanya Lai for assisting with sampling and sample preparation; Lennart Norell, Rick Nordheim, and Peter Crump for the statistical analyses; and The Feed Conservation Program (project leader Magne Mo) at the Department of Animal and Aquacultural Sciences, Norwegian University of Life Sciences for funding travels to the United States.

\section{REFERENCES}

Andries, J. I., F. X. Buysse, D. L. Debrabander, and B. G. Cottyn. 1987. Isoacids in ruminant nutrition: Their role in ruminal and intermediary metabolism and possible influences on performances-A review. Anim. Feed Sci. Technol. 18:169-180.

AOAC. 1980. Official Methods of Analysis. 13th ed. Association of Official Analytical Chemists, Washington, DC.

AOAC. 1997. Official Methods of Analysis. 16th ed. Association of Official Analytical Chemists, Arlington, VA.

Bach Knudsen, K. E. 1997. Carbohydrate and lignin contents of plant materials used in animal feeding. Anim. Feed Sci. Technol. 67:319-338.

Broderick, G. A. 1992. Relative value of fish meal versus solvent soybean meal for lactating dairy cows fed alfalfa silage as sole forage. J. Dairy Sci. 75:174-183.

Broderick, G. A. 1995. Desirable characteristics of forage legumes for improving protein utilization in ruminants. J. Anim. Sci. 73:2760-2773.

Broderick, G. A. 2003. Effects of varying dietary protein and energy levels on the production of lactating dairy cows. J. Dairy Sci. 86:1370-1381.

Broderick, G. A., and M. K. Clayton. 1997. A statistical evaluation of animal and nutritional factors influencing concentrations of milk urea nitrogen. J. Dairy Sci. 80:2964-2971.

Broderick, G. A., D. B. Ricker, and L. S. Driver. 1990. Expeller soybean meal and corn by-products versus solvent soybean meal for lactating dairy cows fed alfalfa silage as sole forage. J. Dairy Sci. 73:453-462. 
Broderick, G. A., P. Uden, M. L. Murphy, and A. Lapins. 2004. Sources of variation in rates of in vitro ruminal protein degradation. J. Dairy Sci. 87:1345-1359.

Brotz, P. G., and D. M. Schaefer. 1987. Simultaneous determination of lactic and volatile fatty acids in microbial fermentation extracts by gas-liquid chromatography. J. Microbiol. Methods 6:139-144.

Cochran, R. C., D. C. Adams, J. D. Wallace, and M. L. Galyean. 1986. Predicting digestibility of different diets with internal markers: Evaluation of four potential markers. J. Anim. Sci. 63:1476-1483.

Cunningham, M. D., and T. W. Perry. 1972. Roasted corn for growing dairy heifers and for lambs. J. Dairy Sci. 55:367-371.

Davis, A. W., and W. B. Hall. 1969. Cyclic change-over designs. Biometrika 56:283-293.

Ekinci, C., and G. A. Broderick. 1997. Effect of processing high moisture ear corn on ruminal fermentation and milk yield. J. Dairy Sci. 80:3298-3307.

Faldet, M. A., and L. D. Satter. 1991. Feeding heat-treated full fat soybeans to cows in early lactation. J. Dairy Sci. 74:3047-3054.

Felsman, R. J., R. W. Harvey, and E. R. Barrick. 1972. Effect of roasting corn on grain characteristics and cattle performance. J. Anim. Sci. 34:358. (Abstr.)

Firkins, J. L., A. N. Hristov, M. B. Hall, G. A. Varga, and N. R. St Pierre. 2006. Integration of ruminal metabolism in dairy cattle. J. Dairy Sci. 89(E Suppl.):E31-E51.

Grant, R. J., V. F. Colenbrander, and D. R. Mertens. 1990. Milk fat depression in dairy cows: Role of silage particle size. J. Dairy Sci. 73:1834-1842.

Huhtanen, P., K. Kaustell, and S. Jaakkola. 1994. The use of internal markers to predict total digestibility and duodenal flow of nutrients in catttle given six different diets. Anim. Feed Sci. Technol. $48: 211-227$

Huhtanen, P., J. I. Nousiainen, H. Khalili, S. Jaakkola, and T. Heikkila. 2003. Relationships between silage fermentation characteristics and milk production parameters: Analyses of literature data. Livest. Prod. Sci. 81:57-73.

Karkalas, J. 1985. An improved enzymatic method for the determination of native and modified starch. J. Sci. Food Agric. 36:10191027.

Keady, T. W. J., and C. S. Mayne. 2001. The effects of concentrate energy source on feed intake and rumen fermentation parameters of dairy cows offered a range of grass silages. Anim. Feed Sci. Technol. 90:117-129.

Krause, K. M., D. K. Combs, and K. A. Beauchemin. 2003. Effects of increasing levels of refined cornstarch in the diet of lactating dairy cows on performance and ruminal pH. J. Dairy Sci. 86:1341-1353.

Lykos, T., G. A. Varga, and D. Casper. 1997. Varying degradation rates of total nonstructural carbohydrates: Effects on ruminal fermentation, blood metabolites, and milk production and composition in high producing Holstein cows. J. Dairy Sci. 80:33413355 .

McDonald, P., A. R. Henderson, and S. J. E. Heron. 1991. The Biochemistry of Silage. Chalcombe Publications, Marlow, UK.

McDougall, E. I. 1948. Studies on ruminant saliva. I. The composition and output of sheep's saliva. Biochem. J. 43:99-109.

Mertens, D. R., M. Allen, J. Carmany, J. Clegg, A. Davidowicz, M. Drouches, K. Frank, D. Gambin, M. Garkie, B. Gildemeister, D. Jeffress, C. S. Jeon, D. Jones, D. Kaplan, G. N. Kim, S. Kobata, D. Main, X. Moua, B. Paul, J. Robertson, D. Taysom, N. Thiex, J. Williams, and M. Wolf. 2002. Gravimetric determination of amylase-treated neutral detergent fiber in feeds with refluxing in beakers or crucibles: Collaborative study. J. AOAC Int. $85: 1217-1240$.

Muck, R. E. 1987. Dry matter level effects on alfalfa silage quality.1. Nitrogen transformations. Trans. Am. Soc. Agric. 30:7-14

Muck, R. E. 1990. Dry matter level effects on alfalfa silage quality.2. Fermentation products and starch hydrolysis. Trans. Am. Soc. Agric. 33:373-381.

Muck, R. E., and P. O'Kiely. 2002. New technologies for ensiling. Pages 334-343 in Proc. XIIIth International Silage Conference, Auchincruive, Scotland. L. M. Gechie and C. Thomas, ed. Scottish Agric. Coll., Auchincruive.

Nagel, S. A., and G. A. Broderick. 1992. Effect of formic acid or formaldehyde treatment of alfalfa silage on nutrient utilization by dairy cows. J. Dairy Sci. 75:140-154.

NRC. 2001. Nutrient Requirements of Dairy Cattle. 7th rev. ed. National Academy Press, Washington, DC.

Olmos Colmenero, J. J., and G. A. Broderick. 2006. Effect of dietary crude protein concentration on milk production and nitrogen utilization in lactating dairy cows. J. Dairy Sci. 89:1704-1712.

Oser, B. L. 1965. Hawk's Physiological Chemistry. 14th ed. McGrawHill, New York, NY.

Overton, T. R., M. R. Cameron, J. P. Elliottt, J. H. Clark, and D. R. Nelson. 1995. Ruminal fermentation and passage of nutrients to the duodenum of lactating cows fed mixture of corn and barley. J. Dairy Sci. 78:1981-1998.

Reeve, R. R., and H. G. Walker. 1969. The microscopic structure of popped cereals. Cereal Chem. 46:227.

Rémond, D., J. I. Cabrera-Estrada, M. Champion, B. Chauveau, R. Coudure, and C. Poncet. 2004. Effect of corn particle size on site and extent of starch digestion in lactating dairy cows. J. Dairy Sci. 87:1389-1399.

SAS Institute. 1999-2000. SAS/STAT User's Guide. Release 8.1. SAS Institute Inc., Cary, NC.

Shingfield, K. J., S. Jaakkola, and P. Huhtanen. 2002. Effect of forage conservation method, concentrate level and propylene glycol on diet digestibility, rumen fermentation, blood metabolite concentrations and nutrient utilisation of dairy cows. Anim. Feed Sci. Technol. 97:1-21.

Sniffen, C. J., J. D. O'Connor, P. J. Van Soest, D. G. Fox, and J. B. Russell. 1992. A net carbohydrate and protein system for evaluating cattle diets. 2. Carbohydrate and protein availability. J. Anim. Sci. 70:3562-3577.

Vagnoni, D. B., and G. A. Broderick. 1997. Effects of supplementation of energy or ruminally undegraded protein to lactating cows fed alfalfa hay or silage. J. Dairy Sci. 80:1703-1712.

Valadares, R. F. D., G. A. Broderick, S. C. V. Filho, and M. K. Clayton. 1999. Effect of replacing alfalfa silage with high moisture corn on ruminal protein synthesis estimated from excretion of total purine derivatives. J. Dairy Sci. 82:2686-2696.

Van Soest, P. J. 1994. Nutritional Ecology of the Ruminant. Cornell University Press, Ithaca, NY.

Van Soest, P. J., J. B. Robertson, and B. A. Lewis. 1991. Methods for dietary fiber, neutral detergent fiber, and nonstarch polysaccharides in relation to animal nutrition. J. Dairy Sci. 74:35833597.

Vogels, G. D., and C. van der Drift. 1970. Differential analyses of glyoxylate derivatives. Anal. Biochem. 33:143-157. 